\title{
CORRIGENDA
}

\section{Effect of silencing PARG in human colon carcinoma LoVo cells on the ability of HUVEC migration and proliferation}

J Pan, NJS Fauzee, Y-I Wang, Y-T Sheng, Y Tang, J-Q Wang, W-q Wu, J-x Yan and J Xu

Cancer Gene Therapy (2013) 20, 701-702; doi:10.1038/cgt.2013.75

Correction to: Cancer Gene Therapy (2012) 19, 715-722; doi:10.1038/cgt.2012.48; published online 24 August 2012
Figures 1 and 2 in this article were published with errors. The correct figure parts, and their legends, are reproduced correctly here. The authors regret the errors.
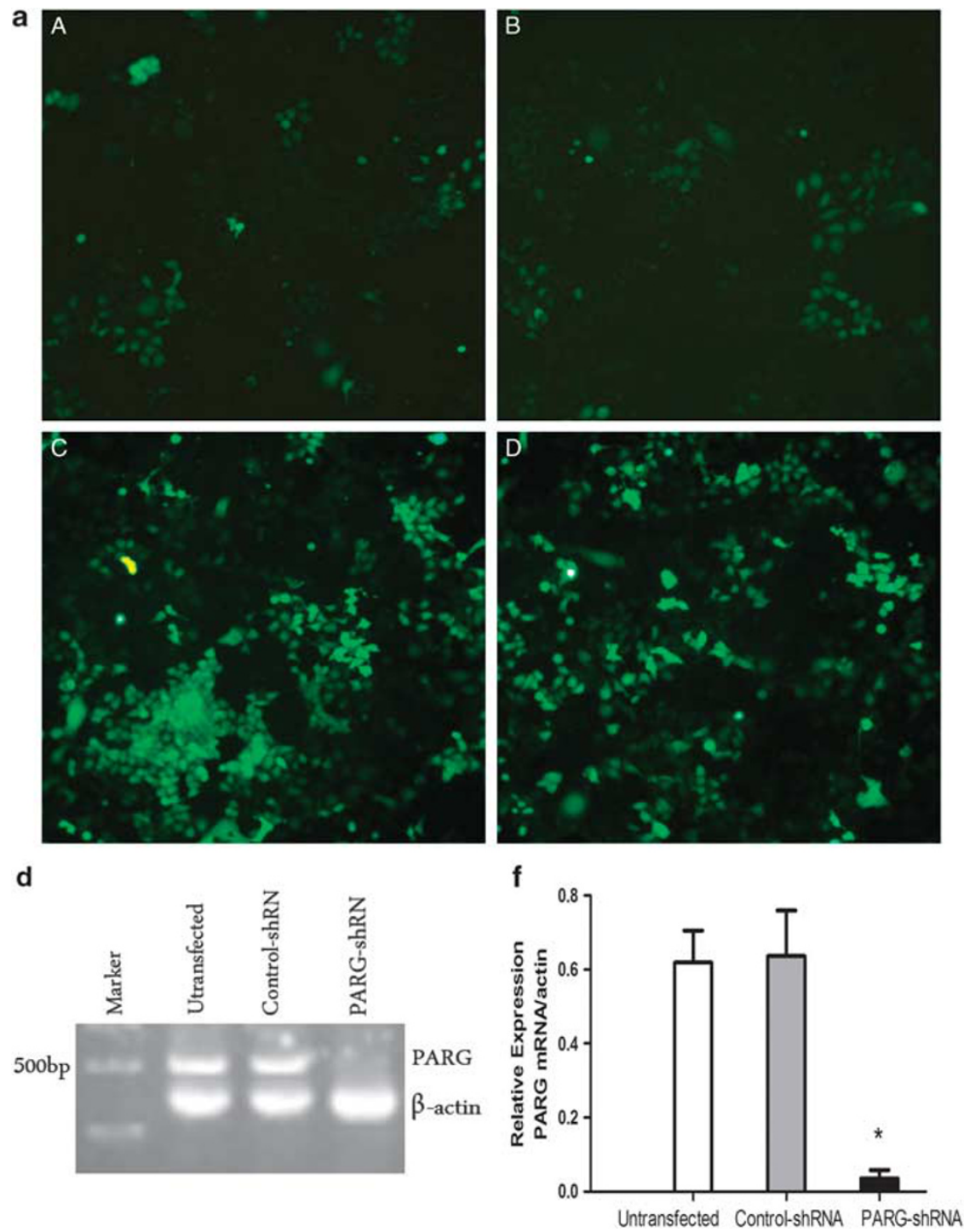

Figure 1. (a) LoVo cells transfected with TurboGFP $(\times 400)$. In all, 2, 5, 10 and $15 \mu$ l of lentiviral particles containing TurboGFP were transfected into LoVo cells. After $48 \mathrm{~h}$ of incubation at $37^{\circ} \mathrm{C}$ fluorescin was displayed in LoVo cells. (A) Represents $2 \mu$ l of lentiviral particles containing the TurboGFP group, (B) 5, (C) 10 and (D) $15 \mu \mathrm{l}$. (d and f) Effect of knockdown PARG by shRNA in LoVo cells. RT-PCR reveals complete inhibition of PARG expression in PARG-shRNA-transfected cells compared with untransfected and control-shRNA cells. $\beta$-Actin was used as an internal loading control. 

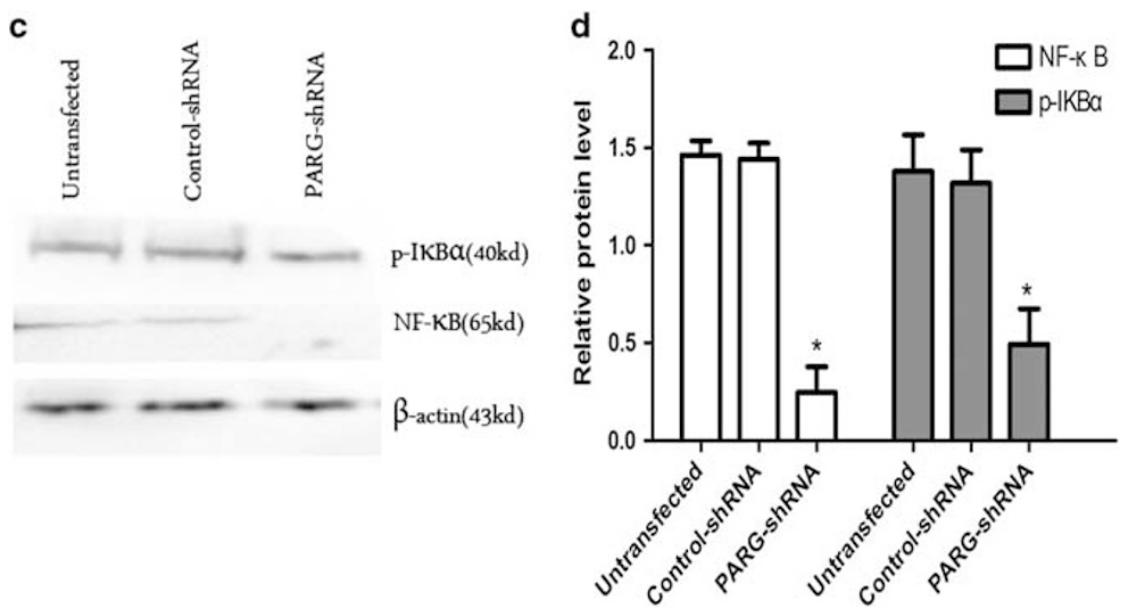

Figure 2. (c and $\mathbf{d}$ ) Western blot analysis highlights a decrease in expression of cytoplasmic $p$-IкB $\alpha$ together with a fall in the intranuclear expression of NFK-B in PARG-shRNA cells compared with both untransfected and control-shRNA cells $\left({ }^{*} P<0.05\right)$.

\section{Combining CAR T cells and the Bcl-2 family apoptosis inhibitor ABT-737 for treating B-cell malignancy}

SCH Karlsson, AC Lindqvist, M Fransson, G Paul-Wetterberg, B Nilsson, M Essand, K Nilsson, P Frisk, H Jernberg-Wiklund and SIA Loskog

Cancer Gene Therapy (2013) 20, 702; doi:10.1038/cgt.2013.76

Correction to: Cancer Gene Therapy (2013) 20, 386-393; doi:10.1038/cgt/2013.35
Two of the authors were listed with incorrect initials. The first author should have been listed as $\mathrm{H}$ Karlsson. The last author should have been listed as A Loskog. The authors regret the errors. 